\title{
Experimental assessment of performance and exhaust emission characteristics of a diesel engine fuelled with Punnai biodiesel/ butanol fuel blends
}

\author{
Yuvarajan Devarajan $^{1} \cdot$ Dineshbabu Munuswamy ${ }^{2} \cdot$ Beemkumar Nagappan $^{3} \cdot$ Ganesan Subbiah $^{4}$
}

Received: 3 April 2019 / Published online: 30 August 2019

(c) The Author(s) 2019

\begin{abstract}
This work examines the effect of butanol as an oxygenated additive to lower carbon monoxide, smoke, nitrogen oxide and hydrocarbon emissions and to improve the performance aspects of Calophyllum inophyllum (Punnai) biodiesel. Singlecylinder, oil-cooled compression ignition engines are employed in this work. Neat Punnai biodiesel (P100) is blended with butanol at $10 \%$ and $20 \%$ by volume and labelled as B10P90 and B20P80, respectively. Methanol and alkaline catalyst (KOH) were used for the transesterification process for biodiesel production. The transesterification technique yielded $88 \%$ biodiesel from raw Punnai oil. Engine tests resulted in lower $\mathrm{CO}$, smoke, $\mathrm{NO}_{\mathrm{x}}$ and $\mathrm{HC}$ emissions when fuelled with both butanol blends when compared to P100. In addition, BSFC (brake-specific fuel consumption) reduced and BTE (brake thermal efficiency) increased with the inclusion of butanol blends (B10 and B20) to neat Punnai biodiesel.
\end{abstract}

Keywords Butanol $\cdot$ Punnai biodiesel $\cdot$ Nitrogen oxide $\cdot$ Carbon dioxide $\cdot$ Engine

$\begin{array}{ll}\text { Abbreviations } \\ \text { ASTM } & \text { American Society for Testing Materials } \\ \text { P100 } & \text { Neat Punnai biodiesel } \\ \text { B10P90 } & 10 \% \text { of butanol + 90\% of Punnai biodiesel } \\ \text { B20P80 } & 20 \% \text { of butanol }+80 \% \text { of Punnai biodiesel } \\ \text { CO } & \text { Carbon monoxide } \\ \mathrm{NO}_{x} & \text { Oxides of nitrogen emission } \\ \text { BSFC } & \text { Brake-specific fuel consumption } \\ \text { HC } & \text { Unburned hydrocarbon } \\ \text { BTE } & \text { Brake thermal efficiency } \\ \text { CI } & \text { Compression ignition } \\ \mathrm{NO}_{x} & \text { Oxides of nitrogen }\end{array}$

Edited by Xiu-Qiu Peng

Yuvarajan Devarajan

dyuvarajan2@gmail.com

1 Department of Mechanical Engineering, Madanapalle Institute of Technology \& Science, Madanapalle, India

2 Department of Mechanical Engineering, Panimalar Engineering College, Chennai, India

3 Department of Mechanical Engineering, Jain University, School of Engineering and Technology, Bangalore, India

4 Department of Mechanical Engineering, Sathyabama Institute of Science and Technology, Chennai, India

\section{Introduction}

Diesel fuel is widely employed as a major fuel in industry, power and transportation areas owing to its high efficiency. Pollutants such as carbon monoxide, smoke and hydrocarbons from diesel fuel combustion have a serious impact on human health and the environment. To facilitate lowering these emissions, fuel derived from a renewable source is highly promising (Devarajan et al. 2019). Biodiesel and bio-alcohols are the potential fuels which could be used in current engines without much alteration (Appavu 2018). These fuels have similar fuel properties to diesel. However, neat biodiesel in a diesel engine results in higher viscosity issues (Ganesan 2019). Hence, the viscosity of neat biodiesel should be lowered as far as possible to minimize the drawbacks mentioned. Many studies were attempted by blending the lower carbon-hydrogen $(\mathrm{C}-\mathrm{H})$ alcohols such as methanol and ethanol which resulted in phase separation leading to poor ignition (Rajesh Kumar and Saravanan 2016; Ramakrishnan et al. 2019). To reduce this drawback, alcohols having a longer $\mathrm{C}-\mathrm{H}$ chain and higher calorific value, namely butanol, pentanol and octanol, are potential additives to diesel-biodiesel blends (Devarajan 2018).

Many studies explored the usage of higher $\mathrm{C}-\mathrm{H}$ alcohols to diesel/biodiesel blends (Joy et al. 2017; Devarajan 2018; Devarajan et al. 2018). Devaraj et al. (2018) have 
found that the addition of higher $\mathrm{C}-\mathrm{H}$ alcohols (pentanol) to diesel reduces $\mathrm{CO}, \mathrm{NO}_{\mathrm{x}}$ emissions. Yuvarajan et al. (2016) confirmed that pentanol addition lowered biodiesel $\mathrm{HC}$ and CO emissions. Kishore Pandian et al. (2017) also agreed with the result stating that the addition of pentanol to biodiesel fuel lowers its $\mathrm{NO}_{\mathrm{x}}$ emissions. Radhakrishnan et al. (2018) evaluated the impact of adding different volumes of pentanol to palm biodiesel in a research engine. They found a $3.9 \%$ reduction in $\mathrm{NO}_{\mathrm{x}}$ emissions by including $20 \%$ volume of higher $\mathrm{C}-\mathrm{H}$ alcohols to palm biodiesel. In addition, they also found that the usage of pentanol reduces $\mathrm{CO}$ and smoke emissions in a diesel engine. Yuvarajan et al. (2019) observed the emission efficiency of cyclo-octanol with biodiesel. Cyclo-octanol addition results in lower tailpipe emissions at low, moderate and high loads. Further, cyclo-octanol also boosts the rate of dispersion in fuel. Pandian et al. (2018) confirmed that hexanol addition lowered biodiesel (cashew nutshell) HC, $\mathrm{CO}$ emissions. Mahalingam (2018) found that the addition of pentanol to biodiesel reduces $\mathrm{CO}, \mathrm{NO}_{\mathrm{x}}$ emissions. Previous literature confirms that the addition of longer $\mathrm{C}-\mathrm{H}$ chain and higher calorific value, namely butanol, pentanol and octanol, to diesel/biodiesel results in lower emissions and improved fuel efficiency.

\subsection{The reason for employing Punnai oil as a source of biodiesel}

Punnai seeds obtained from the Punnai tree yield raw oil on drying and crushing. The oil obtained from these seeds is nontoxic, free from sulphur and aromatics and biodegradable. It also has a high boiling point, cetane number and flash point, low vapour pressure and high density which enhance the running of engines. It has been found that $1 \mathrm{~kg}$ of Punnai seeds yields $420 \mathrm{ml}$ of Punnai oil.

\subsection{Novelty of this work}

Information from the previous work shows that adding higher alcohols, namely butanol, pentanol, hexanol and octanol, in certain volume proportions to diesel/biodiesel and its blends is an effective way of reducing the associated emissions. However, no specific work has been conducted on using nonedible Punnai biodiesel as a neat fuel in compression ignition engine applications. Further, the detailed investigation of the effect of butanol in Punnai biodiesel has not been attempted before. Hence, this study details the outcome of using butanol as an oxygendonating additive on emissions and performance patterns of Punnai biodiesel in a diesel engine.
Table 1 Properties of butanol

\begin{tabular}{ll}
\hline Energy density & $29.1 \mathrm{MJ} / \mathrm{L}$ \\
Air-fuel ratio & 11.2 \\
Specific energy & $3 \mathrm{MJ} / \mathrm{kg}$ air \\
Heat of vaporization & $0.92 \mathrm{MJ} / \mathrm{kg}$ \\
Kinematic viscosity & $3.54 \mathrm{~mm}^{2} / \mathrm{s}$ \\
\hline
\end{tabular}

Table 2 Fatty acid compositions of base fuel

\begin{tabular}{ll}
\hline Fatty acids & P100 (\% mass) \\
\hline Lauric C12:0 & Trace \\
Myristic C14:0 & 0.24 \\
Palmitic C16:0 & 26.88 \\
Stearic C18:0 & 29.32 \\
Oleic C18:1 & 32.30 \\
Linoleic C18:2 & 11.22 \\
\hline
\end{tabular}

\section{Materials and methods}

\subsection{Butanol}

Butanol contains ten hydrogen and four carbon atoms with the molecular formula of $\mathrm{C}_{4} \mathrm{H}_{10} \mathrm{O}$ and is classified as a higher alcohol. Since it has a longer $\mathrm{C}-\mathrm{H}$ chain, it can be used as neat CI engine fuel. Butanol is obtained by anaerobic fermentation. It is a flammable and colourless alcohol having a calorific value of $29,200 \mathrm{~kJ} / \mathrm{Kg}$, a self-ignition temperature of $340{ }^{\circ} \mathrm{C}$ and kinematic viscosity of 2.6 psi. Butanol, when blended with Punnai biodiesel, lowers the overall viscosity which has a positive impact on ignition properties. Improved properties, eco-friendly nature and ease in availability make butanol an encouraging additive to biodiesel/diesel fuels. Table 1 shows the properties of butanol.

\subsection{Fuel preparation}

Alkaline transesterification was employed for the biodiesel production from Punnai oil. Hundred grams of Punnai oil was taken in a conical flask and mixed with $0.5 \%$ (weight\%) of $\mathrm{KOH}$ and methanol at a ratio of 5:1 and heated to $85^{\circ} \mathrm{C}$. Then, the mixture was stirred constantly at $55{ }^{\circ} \mathrm{C}$ for a reaction time of $40 \mathrm{~min}$ and kept uninterrupted for phase separation. The upper layer was of Punnai biodiesel while glycerol settled at the base. The conversion ratio of the oil to biodiesel was found to be $88 \%(500 \mathrm{ml}$ of raw oil yielded $440 \mathrm{ml}$ of biodiesel). Table 2 shows the fatty acid composition of base fuel. A volume fraction 
Table 3 Properties of tested fuels

\begin{tabular}{lllllll}
\hline Properties & P100 & B10P90 & B20P80 & Diesel & Allowable limit & Method \\
\hline Density @ $15{ }^{\circ} \mathrm{C}$, gm $/ \mathrm{cc}$ & 0.77 & 0.75 & 0.73 & 0.75 & $0.65-0.86$ & ASTM D4052 \\
Kinematic viscosity @ $40{ }^{\circ} \mathrm{C}, \mathrm{mm}^{2} / \mathrm{s}$ & 4.8 & 4.5 & 4.2 & 2.7 & $1.9-6.5$ & ASTM D445 \\
Calorific value, $\mathrm{kJ} / \mathrm{kg}$ & 37,698 & 38,125 & 38,623 & 42,500 & $>15,000$ & ASTM D240 \\
Flash point, ${ }^{\circ} \mathrm{C}$ & 154 & 155 & 157 & 45 & $>40$ & ASTM D824 \\
Cetane index, CI & 54 & 55 & 55 & 47 & $>47$ & ASTM D976 \\
\hline
\end{tabular}

Table 4 Specification of the experimental setup

\begin{tabular}{ll}
\hline Make & Kirloskar \\
Stroke & 4 \\
Cylinder & Single \\
Rated power & $5.5 \mathrm{~kW}$ \\
Rated speed & $1500 \mathrm{rpm}$ \\
Bore diameter (D) & $87.5 \mathrm{~mm}$ \\
Stroke (L) & $110 \mathrm{~mm}$ \\
Compression ratio & $17.5: 1$ \\
Injection timing & $17^{\circ} \mathrm{bTDC}$ \\
\hline
\end{tabular}

of $10 \%$ and $20 \%$ of butanol was dispersed in neat Punnai biodiesel using an R-4C ultrasonicator and labelled as B10P90 and B20P80, respectively.

\subsection{Stability testing}

The stability of butanol in P100 was investigated using a UV-visible spectrometer. Subsequently, the dispersion of butanol in P100 was studied with a gravitational procedure. No notable separation in phase was found between butanol and P100. P100-butanol blends (B10P90 and B20P80) and Punnai biodiesel (P100) were fuelled separately for further investigations. The physical and chemical properties of B10P90, B20P80 and P100 are shown in Table 3.

\subsection{Experimental setup}

The entire fuel sample (B10P90 and B20P80, and P100) was fed to the engine fuel test tube with a particle filter at controlled ambient temperature. The flow meter was connected to the fuel test tube to compute fuel consumption. Engine load was generated by a resistor bank. A Di-gas exhaust gas analyser from AVL was employed to measure the NOx,

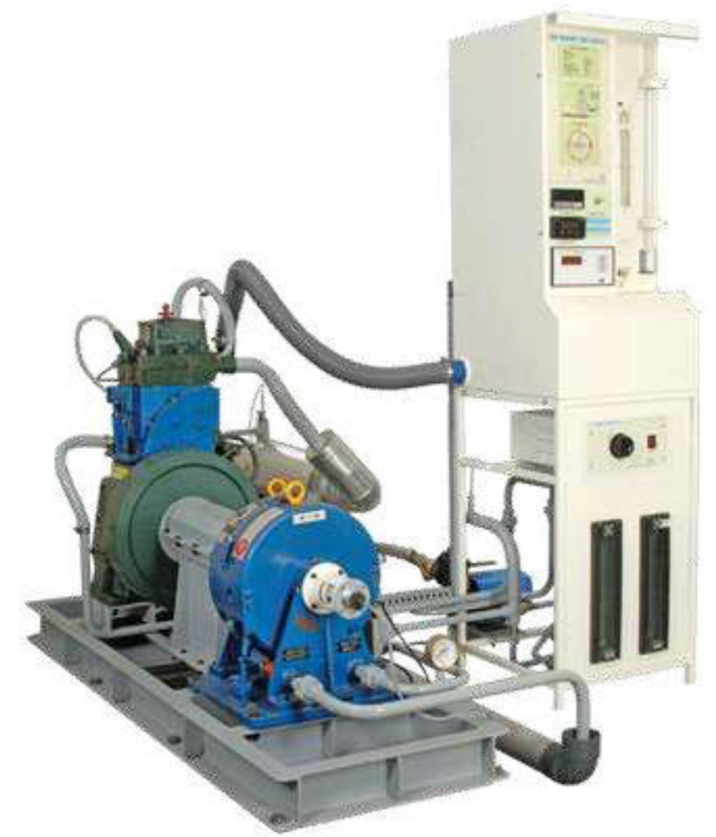

Fig. 1 Photographic view of the experimental setup

hydrocarbons (HC), smoke opacity, carbon monoxide (CO) emissions from the fuels. Testing was performed on a single-cylinder, manual, oil-cooled, four-stroke engine. Table 4 illustrates other engine specifications. Figure 1 shows a photograph of the test engine.

\subsection{Uncertainty analysis}

Systematic and random uncertainties were computed from five repetitions ( $n=5$ ) by carefully checking each instrument, method and its calibrations. For every parameter tested, the instrumental uncertainties are combined with the experimental uncertainties (total uncertainties = instrumental + experimental). The final result of each sample was the quadratic sum of each of the expanded uncertainties indicated in Eq. (1):

$W_{\mathrm{R}}=\sqrt{\left[\left(\frac{\partial R}{\partial x_{1}} W_{1}\right)^{2}+\left(\frac{\partial R}{\partial x_{2}} W_{2}\right)^{2}+\left(\frac{\partial R}{\partial x_{3}} W_{3}\right)^{2}+\cdots\left(\frac{\partial R}{\partial x_{n}} W_{n}\right)^{2}\right]}$ 
where $W_{\mathrm{R}}=\frac{\delta R}{R} ; \pm \delta R$ is the error in $R$.

\section{Results and discussion}

\subsection{Physicochemical properties of test fuels}

The kinematic viscosity of diesel is lower than Punnai biodiesel. Adding butanol to Punnai biodiesel lowers its viscosity and makes it closer to diesel. The heating value of diesel is 5.8\% superior to Punnai biodiesel (PBD). Adding butanol to PBD lowers the calorific value by $4.1 \%$. This reduction is due to the lower calorific value of butanol (Sudalaimuthu et al. 2018). The higher molecular weight and the structure of PBD make it 3.6\% denser than diesel (Vellaiyan et al. 2019). It is well known that the flash point of all the biodiesel is significantly higher than diesel, which makes it safer to handle and to transport (Radhakrishnan 2017; Rajesh Kumar et al. 2016). The cetane indexes of the Punnai fuels (B10P90, B20P80 and P100) are significantly higher than diesel owing the higher degree of unsaturation.

\subsection{Hydrocarbon emissions}

$\mathrm{HC}$ emissions for P100, B10P90, diesel and B20P80 are shown in Fig. 2. HC emissions rise sharply with load for all fuels. With an increase in load, the mixture gets rich and aids incomplete combustion and higher HC emissions. HC emissions from biofuels are lower than diesel. This is due to its higher carbon atom and oxygen content (Balan et al. 2018). Adding butanol to Punnai biodiesel lowers its HC emissions. This is due to the increase in the rate in the combustion process. Butanol acts as an oxygenated catalyst and leads to more complete combustion and lower HC emissions (Devarajan et al. 2017). HC emissions from B20P80 are $2.7 \%$ lower than B10P90. This reduction is due to the lower

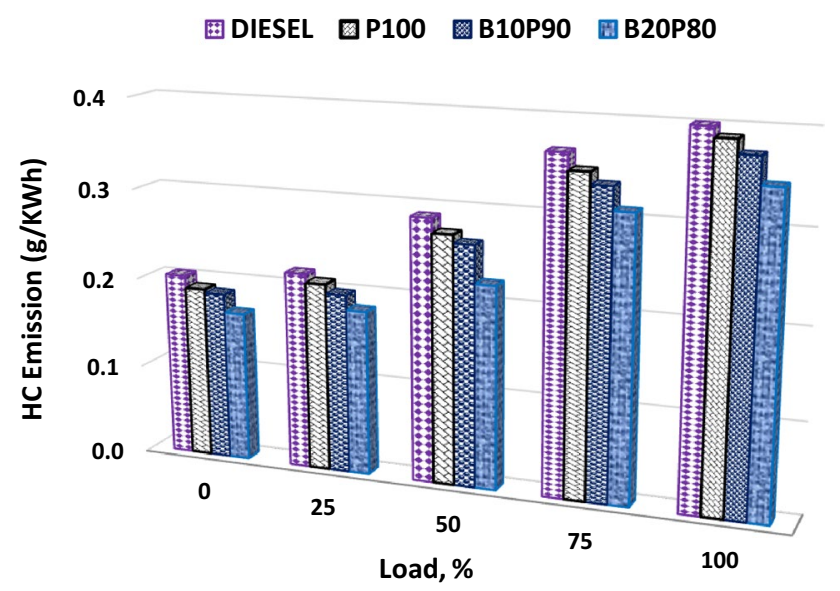

Fig. 2 Variation in $\mathrm{HC}$ emissions with load viscosity of B20P80. Fuel with lower viscosity improves the atomization process and results in lower HC emissions (Saravanan et al. 2017). B10P90 produces $1.9 \%$ lower HC emissions than $\mathrm{P} 100$, while B20P80 produces $2.8 \%$ lower HC emissions than P100.

\subsection{Carbon monoxide emissions}

Change in $\mathrm{CO}$ emissions for P100, B10P90, diesel and B20P80 is shown in Fig. 3. CO emissions rise with load for all fuels. This is due to the formation of a rich mixture under load (Radhakrishnan 2017; Rathinam et al. 2018). $\mathrm{CO}$ emissions for P100, B10P90 and B20P80 are considerably lower than diesel owing to its natural oxygen content (Vellaiyan et al. 2019). Further, the oxygen present in Punnai biodiesel and butanol blends significantly improves the combustion efficiency and lowers CO emissions. B10P90 and $\mathrm{B} 20 \mathrm{P} 80$ produce lower $\mathrm{CO}$ emissions than $\mathrm{P} 100$ and diesel. The oxygen-donating catalysts in butanol activate the combustion reaction and lower $\mathrm{CO}$ emissions (Arulprakasajothi et al. 2018). B20P80 produces $1.2 \%$ lower CO emissions than B10P90. The lower viscosity of B20P80 enhances the chemical reaction and lessens the delay period and $\mathrm{CO}$ emissions. B10P90 produces $1.9 \%$ lower $\mathrm{CO}$ emissions than P100, while B20P80 produces $2.8 \%$ lower $\mathrm{CO}$ emissions than P100. The obtained results agree with numerous other experimental works performed on alcohol/biodiesel/diesel blends (Senthilkumar et al. 2018; Venu and Madhavan 2016; Sivamurugan and Devarajan 2018).

\subsection{Smoke opacity}

Figure 4 illustrates the change in smoke emissions for B10P90, B20P80, P100 and diesel. Smoke emissions increase with load for all test fuels. With the rise in load,

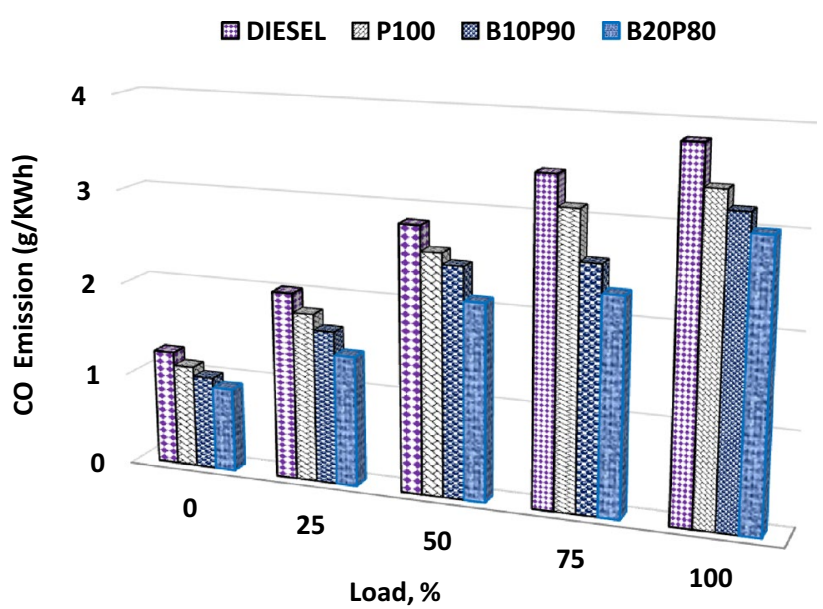

Fig. 3 Variation in $\mathrm{CO}$ emissions with load 


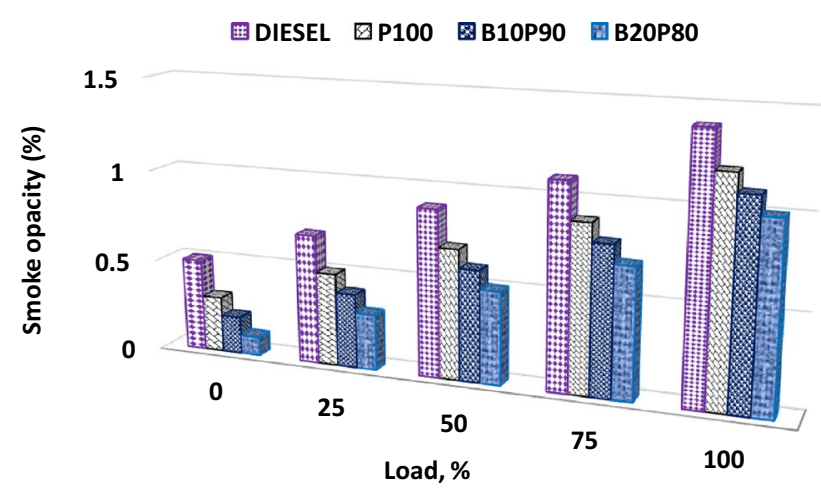

Fig. 4 Variation in smoke opacity with load

an additional quantity of fuel is supplied with the same magnitude of air in the cylinder, which makes the fuel-air richer and aids incomplete combustion and elevated smoke emissions. P100 produces more smoke than B10P90 and $\mathrm{B} 20 \mathrm{P} 80$. The atomization process of air is improved by the oxygen-rich fuels, namely B10P90 and B20P80. The finer atomization reduces fuel accumulation and enhances the rate of combustion. B20P80 produces less smoke than B10P90 and P100. This is because of the improved evaporation rate and enhanced ignition properties of a higher percentage of butanol in B20P80. B10P90 produces 2.3\% lower smoke emissions than $\mathrm{P} 100$, while $\mathrm{B} 20 \mathrm{P} 80$ produces $3.6 \%$ lower smoke emissions than P100.

\subsection{Oxides of nitrogen emissions}

$\mathrm{NO}_{\mathrm{x}}$ emissions for P100, B10P90 and B20P80 are shown in Fig. 5. $\mathrm{NO}_{\mathrm{x}}$ emissions increase with load for all fuels. At higher loads, the mixture gets rich and aids incomplete combustion and higher $\mathrm{NO}_{\mathrm{x}}$ emissions (Joy and Beemkumar 2019). $\mathrm{NO}_{\mathrm{x}}$ emissions from biofuels are higher than diesel (Devarajan et al. 2019). This is due to high

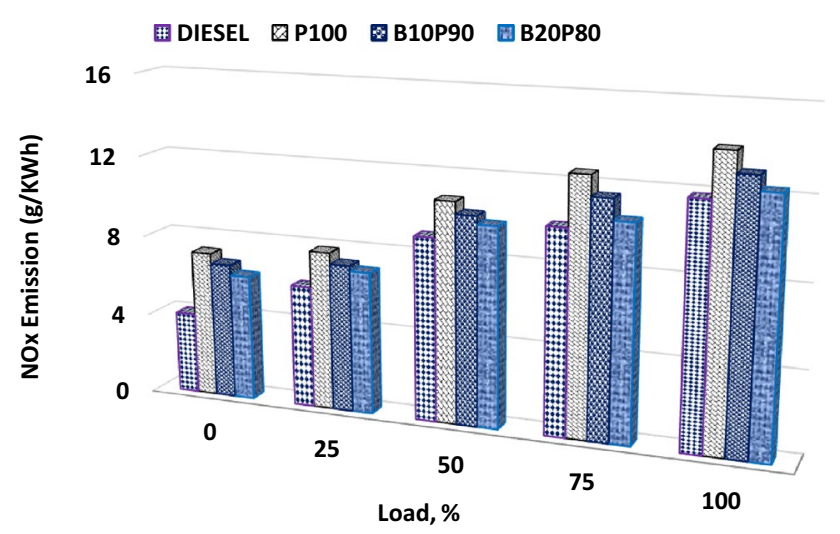

Fig. 5 Variation in $\mathrm{NO}_{\mathrm{x}}$ emissions with load combustion temperature attained during combustion. Adding butanol to Punnai biodiesel lowers its $\mathrm{NO}_{\mathrm{x}}$ emissions. This is due to the increase in the rate in the combustion process (Radhakrishnan 2017). Butanol acts as an oxygenated catalyst and leads to lower combustion temperature and lower $\mathrm{NO}_{\mathrm{x}}$ emissions. $\mathrm{NO}_{\mathrm{x}}$ emissions from $\mathrm{B} 20 \mathrm{P} 80$ are $1.8 \%$ lower than $\mathrm{B} 10 \mathrm{P} 90$. This reduction is due to the lower viscosity of B20P80. Fuel with lower viscosity improves the atomization process, reduces ignition delay and lowers $\mathrm{NO}_{\mathrm{x}}$ emissions (Yuvarajan and Ramanan 2016). $\mathrm{B} 10 \mathrm{P} 90$ produces $1.2 \%$ lower $\mathrm{NO}_{\mathrm{x}}$ emissions than $\mathrm{P} 100$, while $\mathrm{B} 20 \mathrm{P} 80$ produces $1.7 \%$ lower $\mathrm{NO}_{\mathrm{x}}$ emissions than P100.

\subsection{Carbon dioxide emission}

Change in $\mathrm{CO}_{2}$ emissions for $\mathrm{P} 100, \mathrm{~B} 10 \mathrm{P} 90$, diesel and B20P80 is shown in Fig. 6. $\mathrm{CO}_{2}$ emissions for P100, $\mathrm{B} 10 \mathrm{P} 90$ and B20P80 are considerably lower than diesel owing to its natural oxygen content (Vellaiyan et al. 2019). Further, the oxygen present in Punnai biodiesel and butanol blends significantly improves the combustion efficiency and lowers $\mathrm{CO}_{2}$ emissions. B10P90 and B20P80 produce lower $\mathrm{CO}_{2}$ emissions than $\mathrm{P} 100$ and diesel. The oxygen-donating catalysts present in butanol activate the combustion reaction and lower $\mathrm{CO}_{2}$ emissions (Arulprakasajothi et al. 2018). B20P80 produces 0.8\% higher $\mathrm{CO}_{2}$ emissions than B10P90.The lower viscosity of B20P80 enhances the chemical reaction and lessens the delay period and lowers $\mathrm{CO}_{2}$ emissions. B10P90 produces $1.6 \%$ lower $\mathrm{CO}_{2}$ emissions than $\mathrm{P} 100$, while $\mathrm{B} 20 \mathrm{P} 80$ produces $2.1 \%$ lower $\mathrm{CO}_{2}$ emissions than P100. The obtained results agree with numerous other experimental works performed on alcohol/biodiesel/diesel blends.

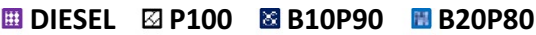

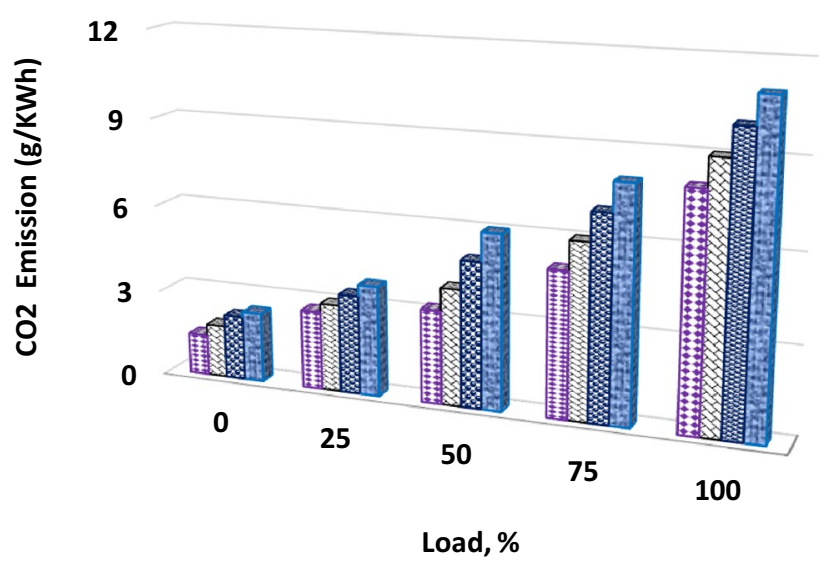

Fig. 6 Variation in $\mathrm{CO}_{2}$ emissions with load 


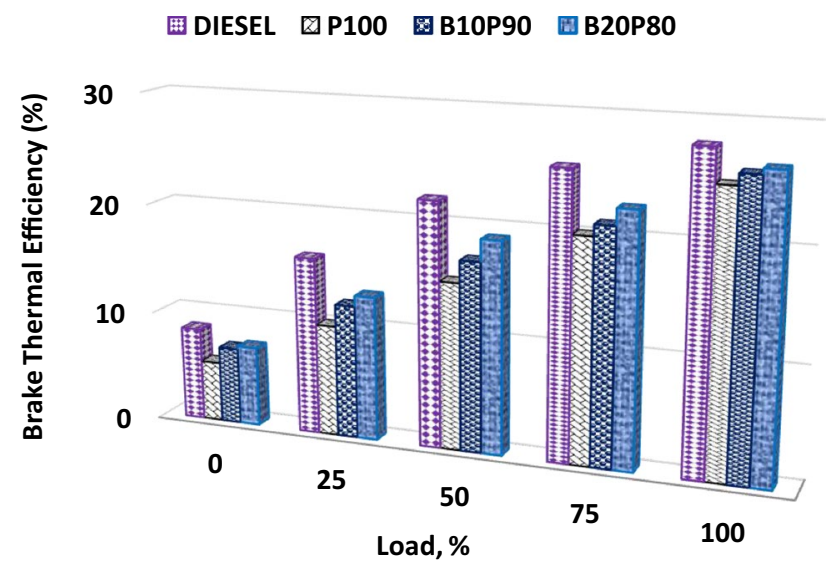

Fig. 7 Variation in BTE with load

\subsection{Brake thermal efficiency}

Change in BTE for P100, B10P90, diesel and B20P80 is shown in Fig. 7. BTE for all fuels increases significantly with the load. At higher loads, the mass of fuel supplied is increased which in turn increases the brake power and BTE. BTE for P100, B10P90 and B20P80 is lower than diesel at all loads. Fuel with higher calorific value requires less quantity of fuel to be supplied. This lower supply of fuel is inversely proportional to BTE. BTE for B10P90, B20P80 is $0.7 \%$ and $1.1 \%$ higher than P100 at $100 \%$ load. The lower viscosity of B10P90, B20P80 lowers the delay period and enhances the atomization process and produces higher BTE. The average BTE from $\mathrm{B} 20 \mathrm{P} 80$ is $2.2 \%$ higher than $\mathrm{B} 10 \mathrm{P} 90$. This enhancement is due to the lower viscosity of B20P80. Fuel with lower viscosity improves the atomization process and enhances combustion efficiency and BTE. The obtained results agree with numerous other experimental works performed on alcohol/biodiesel/diesel blends (Senthilkumar et al. 2018; Venu and Madhavan 2016; Siva et al. 2018; Rajesh Kumar and Saravanan 2015).

\subsection{Brake-specific fuel consumption}

Figure 8 illustrates the change in BSFC for B10P90, B20P80, P100 and diesel. BSFC reduces with load for all test fuels. With a rise in load, an additional quantity of fuel is supplied to sustain the combustion process which leads to higher power output and lower BSFC. P100 produces higher BSFC than B10P90 and B20P80. The atomization process of air is improved by the oxygen-rich fuels, namely B10P90 and B20P80. The finer atomization reduces fuel accumulation, enhances the rate of combustion and lowers BSFC. B20P80 produces lower BSFC than B10P90 and $\mathrm{P} 100$. This is because of improved evaporation rate and enhanced ignition properties of a higher percentage

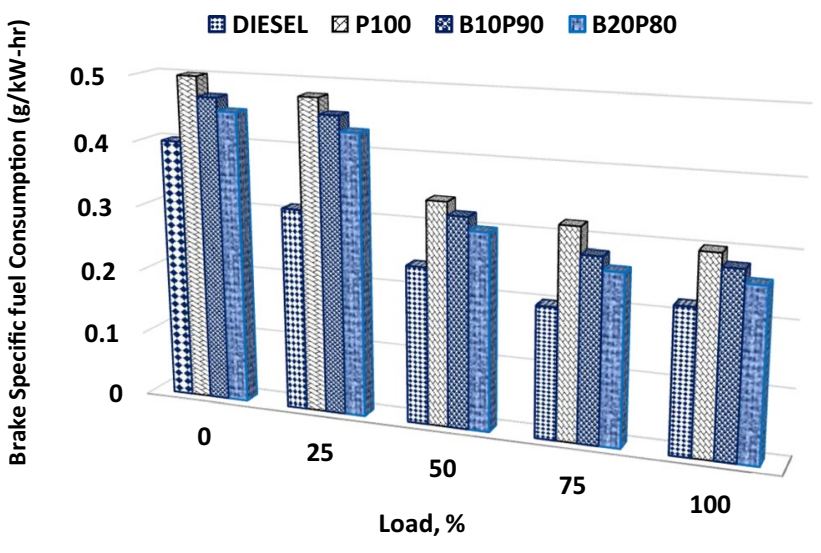

Fig. 8 Variation in BSFC with load

of butanol in B20P80. B10P90 produces 1.3\% lower BSFC than $\mathrm{P} 100$, while $\mathrm{B} 20 \mathrm{P} 80$ produces $1.9 \%$ lower BSFC than P100.

\section{Conclusion}

The consequence of using butanol as a higher alcohol up to $20 \%$ in volume on the emission and performance pattern of Punnai biodiesel/butanol blends was investigated. The following conclusions arise from this study.

- B10P90, B20P80 blends showed the potential results of significant physicochemical properties.

- Smoke opacity decreased for B10P90 with the reduction being even greater for B20P80. Smoke opacity hardly increased due to the dominance of oxygenated conditions for B10P90, B20P80 blends.

- NOx emissions for B10P90, B20P80 blends displayed comparable behaviours under all conditions. NOx emissions lowered with an increase in butanol percentage in the blends.

- The HC emissions were lower for B10P90, B20P80 than P100 under all conditions. This is because of their higher cetane number.

- Increasing butanol content in the P100 improved CO emissions. Butanol has a high heat of vaporization, which enhances the oxidation reaction.

- The BTE of test fuels is: diesel $>$ B20P80 > B10P90 > P100.

- The BSFC of test fuels is: diesel $<$ B20P80 < B10P90 < P100.

- B20P80 demonstrated better emissions and performance patterns among all tested fuels at testing conditions. 
Open Access This article is distributed under the terms of the Creative Commons Attribution 4.0 International License (http://creativeco mmons.org/licenses/by/4.0/), which permits unrestricted use, distribution, and reproduction in any medium, provided you give appropriate credit to the original author(s) and the source, provide a link to the Creative Commons license, and indicate if changes were made.

\section{References}

Appavu P. Effect of injection timing on performance and emission characteristics of palm biodiesel and diesel blends. J Oil Palm Res. 2018;30:674-81. https://doi.org/10.21894/jopr.2018.0057.

Arulprakasajothi M, Chandrasekhar U, Yuvarajan D, Teja MB. An analysis of the implications of air pollutants in Chennai. Int J Ambient Energy. 2018. https://doi.org/10.1080/01430 750.2018.1443504.

Balan KN, Yashvanth U, Booma Devi P, Arvind T, Nelson H, Devarajan Y. Investigation on emission characteristics of alcohol biodiesel blended diesel engine. Energy Sources Part A Recov Util Environ Eff. 2018;41(15):1879-89. https://doi.org/10.1080/15567 036.2018.1549166.

Damodharan D, Sathiyagnanam AP, Rana D, Rajesh Kumar B, Saravanan $\mathrm{S}$. Extraction and characterization of waste plastic oil (WPO) with the effect of $\mathrm{n}$-butanol addition on the performance and emissions of a DI diesel engine fueled with WPO/diesel blends. Energy Convers Manag. 2017;131:117-26. https://doi. org/10.1016/j.enconman.2016.10.076.

Devaraj A, Yuvarajan D, Vinoth Kanna I. Study on the outcome of a cetane improver on the emission characteristics of a diesel engine. Int J Ambient Energy. 2018. https://doi.org/10.1080/01430 750.2018.1492452.

Devarajan Y. Experimental evaluation of combustion, emission and performance of research diesel engine fuelled di-methyl- carbonate and biodiesel blends. Atmos Pollut Res. 2018;10(3):795-801. https://doi.org/10.1016/j.apr.2018.12.007.

Devarajan Y, Munuswamy DB, Mahalingam A. Performance, combustion and emission analysis on the effect of ferrofluid on neat biodiesel. Process Saf Environ Prot. 2017;111:283-91. https://doi. org/10.1016/j.psep.2017.07.021.

Devarajan Y, Munuswamy DB, Nagappan B, Pandian AK. Performance, combustion and emission analysis of mustard oil biodiesel and alcohol blends in diesel engine. Heat Mass Transf. 2018;54(6):1803-11. https://doi.org/10.1007/s00231-018-2274-x.

Devarajan Y, Choubey G, Mehar K. Ignition analysis on neat alcohols and biodiesel blends propelled research compression ignition engine. Energy Sources Part A Recov Util Environ Eff. 2019. https://doi.org/10.1080/15567036.2019.1618998.

Ganesan S. Effect Of EGR \& nanoparticles on performance and emission characteristics of a diesel engine fuelled with palm biodiesel and diesel blends. J Oil Palm Res. 2019;31:130-137. https://doi. org/10.21894/jopr.2018.0065.

Ganesan S, Sivasubramanian R, Sajin JB, Ganesan S, Yuvarajan D. Performance and emission study on the effect of oxygenated additive in neat biodiesel fueled diesel engine. Energy Sources Part A Recov Util Environ Eff. 2018;41(6):2017-27. https://doi. org/10.1080/15567036.2018.1549148.

Joy N, Beemkumar N. Performance evaluation and emission characteristics of biodiesel-ignition enhancer blends propelled in a research diesel engine. Int J Green Energy. 2019;16(4):277-83. https://doi. org/10.1080/15435075.2018.1561455.

Joy N, Devarajan Y, Nagappan B, Anderson A. Exhaust emission study on neat biodiesel and alcohol blends fueled diesel engine. Energy Sour Part A Recovery Util Environ Eff 2017;40(1):115-9. https ://doi.org/10.1080/15567036.2017.1405119.
Kishore Pandian A, Munuswamy DB, Radhakrishnan S, Bathey Ramakrishnan RB, Nagappan B. Influence of an oxygenated additive on emission of an engine fueled with neat biodiesel. Pet Sci. 2017;14(4):791-7. https://doi.org/10.1007/s12182-017-0186-x.

Mahalingam A. Investigation on the emission reduction technique in acetone-biodiesel aspirated diesel engine. J Oil Palm Res. 2018;30(2):345-9. https://doi.org/10.21894/jopr.2018.0020.

Pandian AK, Munuswamy DB, Radhakrishnan S, Ramakrishnan RBB, Nagappan B. Emission and performance analysis of a diesel engine burning cashew nut shell oil bio diesel mixed with hexanol. Pet Sci. 2018;15(1):176-84. https://doi.org/10.1007/s1218 2-017-0208-8.

Radhakrishnan S. Emissions analysis on diesel engine fueled with palm oil biodiesel and pentanol blends. J Oil Palm Res. 2017;29(3):380-6. https://doi.org/10.21894/jopr.2017.2903.11.

Radhakrishnan S, Munuswamy DB, Devarajan Y, Mahalingam A. Performance, emission and combustion study on neat biodiesel and water blends fuelled research diesel engine. Heat Mass Transf. 2018;55(4):1229-37. https://doi.org/10.1007/s00231-018-2509-x.

Rajesh Kumar B, Saravanan S. Effect of exhaust gas recirculation (EGR) on performance and emissions of a constant speed DI diesel engine fueled with pentanol/diesel blends. Fuel. 2015;160:217-26. https://doi.org/10.1016/j.fuel.2015.07.089.

Rajesh Kumar B, Saravanan S. Effects of iso-butanol/diesel and n-pentanol/diesel blends on performance and emissions of a DI diesel engine under premixed LTC (low temperature combustion) mode. Fuel. 2016;170:49-59. https://doi.org/10.1016/j.fuel.2015.12.029.

Rajesh Kumar B, Saravanan S, Rana D, Anish V, Nagendran A. Effect of a sustainable biofuel-n-octanol—on the combustion, performance and emissions of a DI diesel engine under naturally aspirated and exhaust gas recirculation (EGR) modes. Energy Convers Manag. 2016;118:275-86. https://doi.org/10.1016/j.encon man.2016.04.001.

Ramakrishnan G, Krishnan P, Rathinam S, R T, Devarajan Y. Role of nano-additive blended biodiesel on emission characteristics of the research diesel engine. Int J Green Ener. 2019. https://doi. org/10.1080/15435075.2019.1577742.

Rathinam S, Justin Abraham Baby S, Devarajan Y, T A. Influence of water on exhaust emissions on unmodified diesel engine propelled with biodiesel. Energy Sour Part A Recovery Util Environ Eff. 2018. https://doi.org/10.1080/15567036.2018.1503756.

Rathinam S, Balan K, Subbiah G, Sajin J, Devarajan Y. Emission study of a diesel engine fueled with higher alcohol-biodiesel blended fuels. Int J Green Energy. 2019;16(9):667-73. https:// doi.org/10.1080/15435075.2019.1617001.

Saravanan S, Rajesh Kumar B, Varadharajan A, Rana D, Sethuramasamyraja B, Narayana Lakshmi, et al. Optimization of DI diesel engine parameters fueled with iso-butanol/diesel blendsresponse surface methodology approach. Fuel. 2017;203:658-70. https://doi.org/10.1016/j.fuel.2017.04.083.

Senthilkumar G, Sajin JB, Yuvarajan D, Arunkumar T. Evaluation of emission, performance and combustion characteristics of dual fuelled research diesel engine. Environ Technol. 2018. https:// doi.org/10.1080/09593330.2018.1509888.

Siva R, Munuswamy DB, Devarajan Y. Emission and performance study emulsified orange peel oil biodiesel in an aspirated research engine. Pet Sci. 2018. https://doi.org/10.1007/s12182-018-0288-0.

Sivamurugan P, Devarajan Y. Emission analysis of dual fuelled diesel engine. Int J Ambient Ener. 2018. https://doi.org/10.1080/01430 750.2018 .1517696$.

Sudalaimuthu G, Rathinam S, Munuswamy DB, Thirugnanasambandam A, Devarajan Y. Testing and evaluation of performance and emissions characteristics of water- biodiesel aspirated research engine. J Test Eval. 2018;48(5):20180306. https://doi. org/10.1520/jte20180306. 
Vellaiyan S, Partheeban CMA. Emission analysis of diesel engine fueled with soybean biodiesel and its water blends. Energy Sour PartA Recovery Util Environ Eff. 2018;40(16):1956-65. https:// doi.org/10.1080/15567036.2018.1489911.

Vellaiyan S, Subbiah A, Chockalingam P. Multi-response optimization to improve the performance and emissions level of a diesel engine fueled with $\mathrm{ZnO}$ incorporated water emulsified soybean biodiesel/diesel fuel blends. Fuel. 2019;237:1013-20. https://doi. org/10.1016/j.fuel.2018.10.057.

Venu $\mathrm{H}$, Madhavan V. Effect of $\mathrm{Al}_{2} \mathrm{O}_{3}$ nanoparticles in biodiesel-diesel-ethanol blends at various injection strategies: Performance, combustion and emission characteristics. Fuel. 2016;186:176-89. https://doi.org/10.1016/j.fuel.2016.08.046.
Yuvarajan D, Ramanan MV. Effect of magnetite ferrofluid on the performance and emissions characteristics of diesel engine using methyl esters of mustard oil. Arabian J Sci Eng. 2016;41(5):202330. https://doi.org/10.1007/s13369-016-2060-3.

Yuvarajan D, Ravikumar J, Babu MD. Simultaneous optimization of smoke and NOx emissions in a stationary diesel engine fuelled with diesel-oxygenate blends using the grey relational analysis in the Taguchi method. Anal Meth. 2016;8(32):6222-30. https://doi. org/10.1039/C6AY01696K.

Yuvarajan D, Nagappan B, Subbiah G. A comprehensive study on emission and performance characteristics of a diesel engine fueled with nanoparticle-blended biodiesel. Environ Sci Pollut Res. 2019. https://doi.org/10.1007/s11356-019-04446-1. 